\title{
SiM
}

\section{Mitigation of Larkspur Poisoning on Rangelands Through the Selection of Cattle}

\author{
By Benedict T. Green, Kevin D. Welch, James A. Pfister, Carol G. Chitko-McKown, \\ Dale R. Gardner, and Kip E. Panter
}

\section{On the Ground}

- Toxic larkspur (Delphinium species) cause large economic losses from cattle deaths, increased management costs, and reduced utilization of pastures and rangelands.

- We recommend that you obtain a risk assessment for larkspur on your range before turning out the cattle. Submit samples to USDA-ARS Poisonous Plant Research Laboratory for chemical evaluation at no charge. Information is available at: http://www.ars.usda.gov/main/site_main. htm?modecode=54-28-20-00.

- Selection of cattle resistant to larkspur poisoning could reduce cattle losses and improve rangeland utilization.

- The use of genetic-based herd management decisions can provide a tool for livestock producers to improve their profit margin and enhance the economic sustainability of rural American communities.

Keywords: alkaloids, Delphinium, larkspur, cattle, beef, rangelands.

Rangelands 36(1):10-15

doi: 10.2111/RANGELANDS-D-13-00031.1

(c) 2014 The Society for Range Management

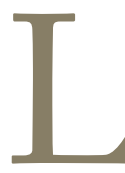

arkspurs (Delphinium spp.) are poisonous plants that negatively impact the earning potential of beef producers in many western rangelands of North America. If ranchers are unfortunate enough to have large stands of toxic larkspur (both tall and low larkspurs) in their pastures, yearly herd mortality can be as high as $10 \%$. Across the western United States, this results in annual economic losses of millions of dollars in animal deaths, increased management and treatment costs, and, if animals are deferred from grazing, the underutilization of otherwise highly nutritious pastures and rangelands. The quality of the ranges where larkspur grow cannot be overemphasized. Stocker cattle grazing on larkspur rangeland can gain upwards of 2.5 pounds per day or more. Furthermore, at the first signs of poisoning many producers move cattle off this high-quality rangeland and leave valuable forage unused. The purpose of this article is to provide a brief review of basic information about larkspur and larkspur poisoning in cattle, and to describe recent research providing evidence that cattle can be selected for resistance to larkspur poisoning.

\section{Larkspur Species}

There are approximately 73 native species of larkspurs in North America, ${ }^{1}$ and these plants are categorized based on plant height and geographical distribution. This classification scheme separates larkspur species into three groups: tall, low, and plains. The majority of cattle losses in the western United States are caused by two groups of larkspur, tall ( $D$. barbeyi and D. occidentale), and low (D. nuttallianum and $D$. andersonii).

Historically, tall larkspurs (Figure 1) have received the most attention; however, low larkspurs (Figure 2) can also be problematic to cattle producers. Tall larkspurs have multiple large hollow stems and plants can have from one to hundreds of stems, depending on the species and growing conditions. Tall larkspurs have wide-bladed leaves growing from slender leaf stalks that are 18 to 36 inches in height with bud clusters on the ends of the stalks. The flowers of all larkspur species have a characteristic spur (Figure 3). Tall larkspur plants grow in high mountain pastures and begin flowering when they have reached about $80 \%$ of their maximum height, which occurs mid- to late July, with the end of flowering occurring about 3 weeks later. Seed pods are high in toxic alkaloids, and begin to form by the end of July and early August from mature flowers. 


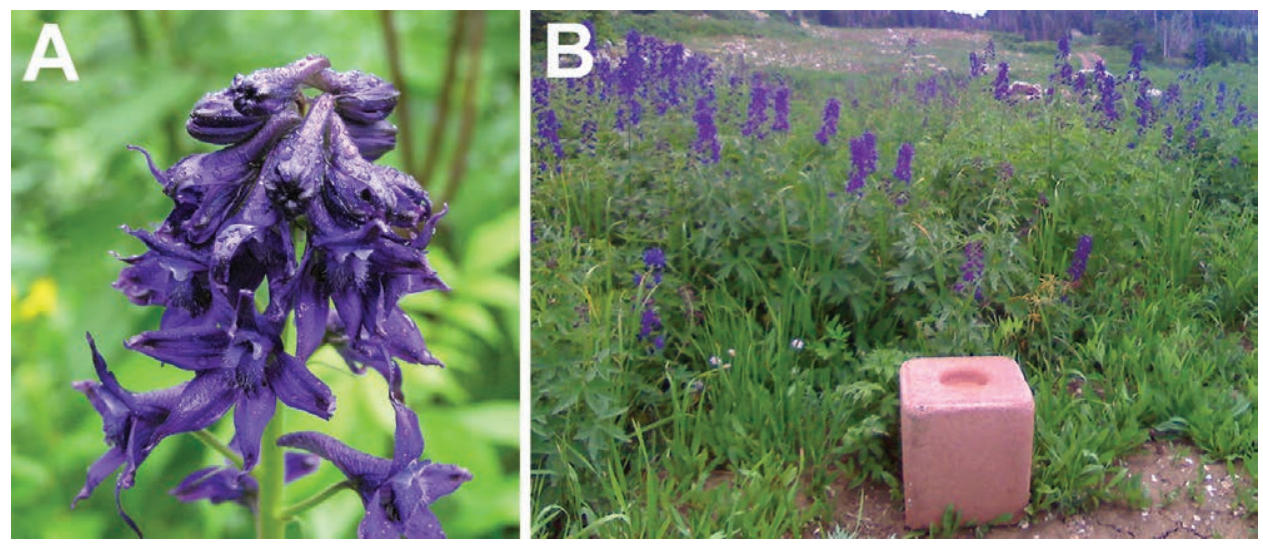

Figure 1. A, Image of a tall larkspur flower and B, typical dense patch of tall larkspur (D. barbeyi) growing near Manti, Utah with a standard-size salt block for reference. Photo A courtesy of Al Schneider.

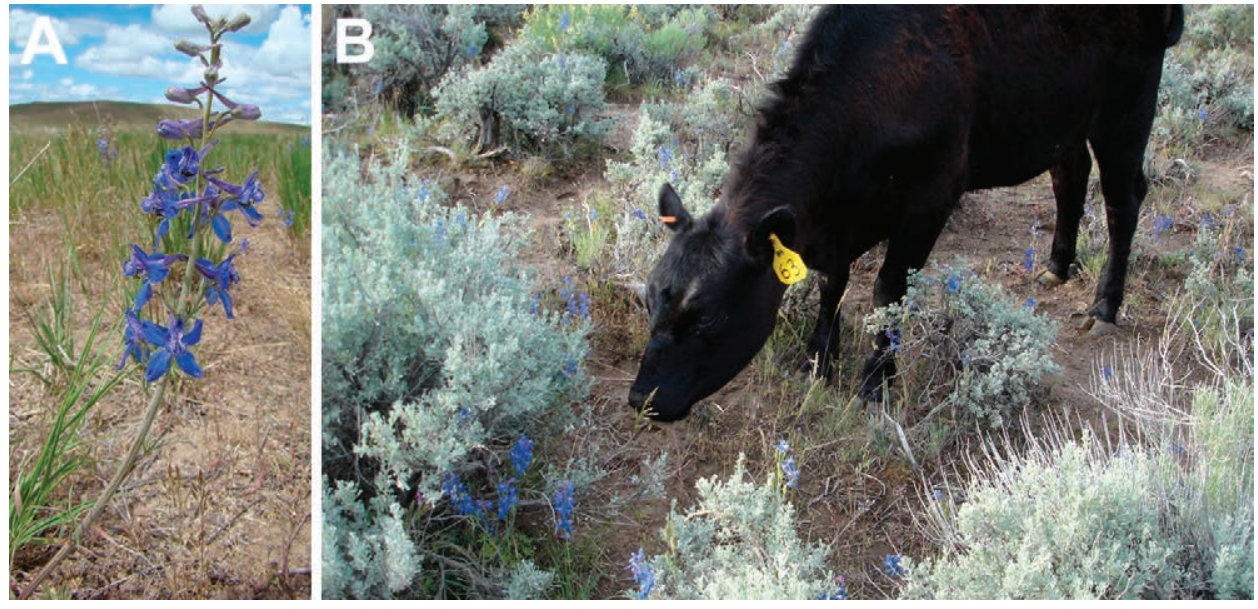

Figure 2. A, Image of low larkspur (D. andersonii)and B, a typical low larkspur-containing sagebrush-steppe ecosystem with cattle grazing near Picabo, Idaho.

The chemical compounds responsible for the toxicity of larkspur in cattle are classified as norditerpenoid alkaloids. The norditerpenoids can be further divided into two classes: the toxic $N$-(methylsuccinimido) anthranoyllycoctonine type (MSAL-type), and the much less toxic 7,8-methylenedioxylycoconine type (MDL-type) alkaloids. Examples of alkaloids from the two classes include methyllycaconitine (abbreviated MLA), a MSAL-type alkaloid; and deltaline, a MDL-type alkaloid. MLA is highly toxic, and deltaline is about 20 times less toxic. Even though less toxic, concentrations of deltaline are typically high in tall larkspurs, and deltaline adds to the toxicity of MLA. The concentrations of these two toxic alkaloids determine the toxic potential of larkspur from a given location. It is important for livestock producers to realize that alkaloid concentrations in larkspur vary by both larkspur species and plant location. ${ }^{2}$ This underscores the importance of producers identifying the species of tall larkspur and the alkaloid content of the plants growing in their pastures. For example, duncecap larkspur (D. occidentale) occurs as one of two different populations (termed chemotypes) of plants that differ in distribution and toxicity. One population is highly toxic to cattle due to high concentrations of MSAL-type alkaloids and the other is only minimally toxic because it contains predominately MDL-type alkaloids. This has been confirmed experimentally with a crossover experiment of two groups of four Angus cattle each dosed with toxic (treatment A) and nontoxic (treatment $\mathrm{B}$ ) chemotypes of duncecap larkspur in opposing treatment order ( $\mathrm{ABA}$ and $\mathrm{BAB})$. In this experiment, only the animals receiving the toxic chemotype (treatment A, containing MSAL-type alkaloids) exhibited muscle weakness and collapse upon exercising behind a tractor at 3-4 miles per hour. Based on the results from these experiments, if a producer has the minimally toxic plant growing in their pastures then the risk of cattle poisoning is greatly reduced. ${ }^{2}$

The other group of larkspur that affects beef producers is the low larkspurs shown in Figure 2. Low larkspurs are located in sagebrush-steppe ecosystems on western foothill and mountain ranges. These plants have fine leaves and stems which reach a height of only 4 to 30 inches. Low larkspurs grow during the spring and senesce during early to mid-summer, depending on elevation and precipitation. ${ }^{3}$ Low larkspur populations tend to increase in response to cool and wet winter and spring conditions, and these dense populations of low larkspur increase the risk to grazing cattle when compared to 


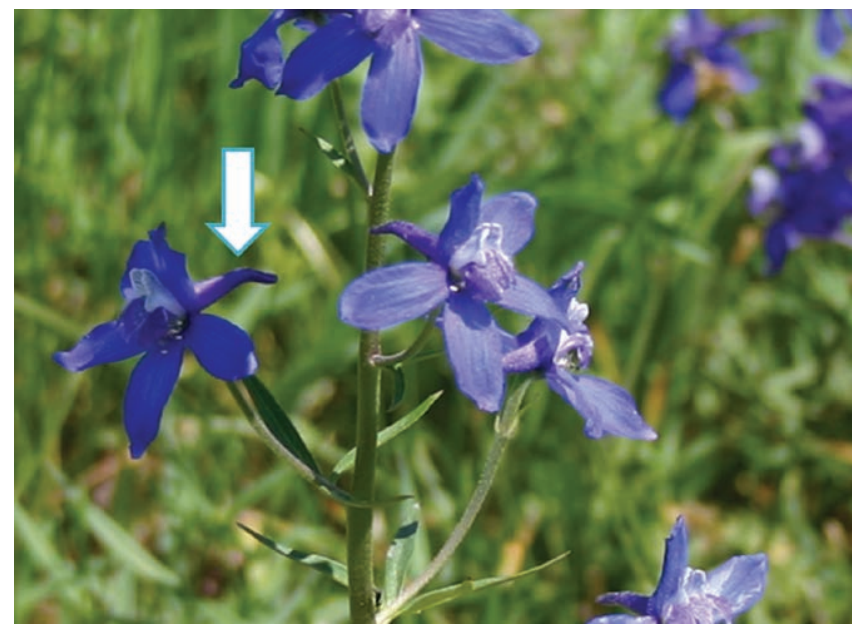

Figure 3. Close-up photo of the larkspur flower demonstrating the spur (arrow) as an identifying feature of all larkspurs.

drier, warmer years. Low larkspurs, like tall larkspurs, contain both MSAL-type and MDL-type alkaloids, and both play a role in toxicity. The two important toxic MSAL-type alkaloids in low larkspur are MLA and nudicauline, and the concentration of these two alkaloids in low larkspur plants can provide an estimation of their toxicity in cattle. ${ }^{4}$ Recent research at the Poisonous Plant Research Laboratory (PPRL) has shown that toxicity of low larkspur alkaloids can vary significantly between cattle breeds and among animals within a given breed. ${ }^{5,6}$ The exact mechanism behind the differences in toxicity between and within breeds is unknown at this time.

\section{Signs of Poisoning in Cattle and Treatment}

When cattle consume large amounts of toxic larkspurs, clinical signs of poisoning occur between 7 and 24 hours after the initial exposure. Typical signs of poisoning include: muscle weakness; trembling and lack of coordination; rapid heart rate; sternal recumbency (i.e., lying on brisket and unable to stand) followed by lateral recumbency (i.e., unable to maintain an upright posture even when lying down); bloating; and death. If cattle are laterally recumbent, it is possible to rescue them with an injection of the drug neostigmine at a dose of $0.02 \mathrm{mg} / \mathrm{kg}$ body weight. ${ }^{7}$ The aim of this treatment is to maintain normal muscle function while providing time for the animal to clear the toxic alkaloids from its body. Some animals could require multiple doses of neostigmine before they clear enough of the larkspur toxins regain muscle strength.

\section{Current Management Options}

Current management recommendations for grazing cattle on larkspur-containing ranges are based on the concentration of toxic alkaloids and growth stage of the larkspur. ${ }^{4}$ Cattle typically consume tall larkspur once it starts to flower and during the pod stage. Cattle prefer the pod stage, and research by PPRL scientists suggests that the preference for pods might be due to high protein content, which is also a period of heightened toxicity. ${ }^{4}$ The period of highest plant toxicity and greatest danger to cattle has been termed the "toxic window" (Figure 4). The toxic window starts at the flower stage and ends in the pod stage for about 5 weeks of elevated toxicity. Managing cattle on larkspur-containing ranges during the toxic window is one tool available to reduce losses. This can be accomplished by: 1) grazing early before the larkspur flowers, 2) removing cattle during the "toxic window," and 3) grazing later in the season when the seed pods begin to shatter. This management option works well, but eliminates grazing these rangelands during their peak productive and nutritional growth phase. By identifying animals naturally resistant to larkspur poisoning, the "toxic window" is narrowed. This increases the amount of grazing time during the early flower stage of plant growth while larkspur palatability is still low but toxicity is increasing. Grazing resistant animals on larkspur-containing ranges can increase productivity and reduce the likelihood of cattle deaths from larkspur.

\section{Experimental Rationale}

Earlier research at the PPRL identified considerable animalto-animal variation in cattle responses to larkspur. ${ }^{2}$ In past larkspur experiments, some cattle within the same breed showed no clinical signs of intoxication while others were severely poisoned. This occurred even though the animals received the same dose of plant on the same day. Based on these observations, we undertook this experiment using halfsibling steers from selected breeds to measure the responses of individual animals. Our goal was to quantify the responses of cattle to a standardized dose of tall larkspur, and to use

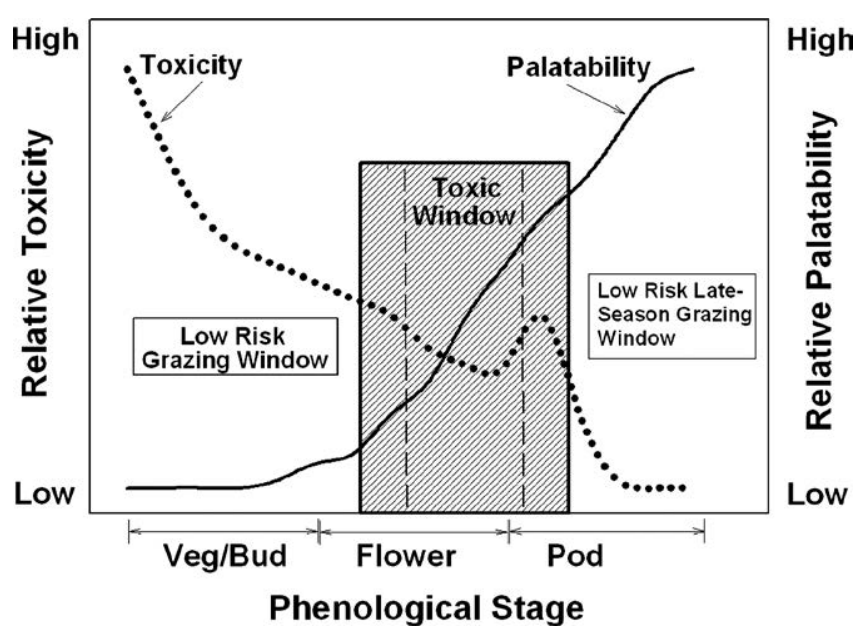

Figure 4. The relationship between larkspur toxicity and palatability from Pfister et al. ${ }^{4}$ The "toxic window" includes the growth stages of the plant when the concentration of toxic alkaloids is elevated, and consumption by cattle begins to increase due to increased palatability. The two vertical dashed lines within the toxic window depict the potential for reducing the width of the window by grazing larkspur-infested rangelands with less susceptible cattle, thus reducing the risk of cattle losses even when the larkspur is highly toxic and increasing in palatability. Currently, there are low-risk grazing windows early in the season before flowering and late in the grazing season after the seed pods shatter. 
that response to identify and classify susceptible and resistant individuals within and between breeds.

\section{Plant Material and Alkaloid Analyses}

Tall larkspur (D. barbeyi) was collected during July 2003 near Manti, Utah (lat 39 $9^{\circ} 03.154^{\prime} \mathrm{N}$, long $111^{\circ} 30.752^{\prime} \mathrm{W}$; PPRL Collections No. 03-12). A voucher specimen was deposited at the Utah State University Herbarium (No. 237494). The plant material was air-dried, ground (2.38- $\mathrm{mm}$ mesh), and mixed by use of a grinder-mixer (Gehl Mix-All model 55, Gehl Co, West Bend, WI). After processing, the plant material was stored in plastic bags away from direct light at ambient temperature until use. The alkaloid content of the larkspur collection ( $4 \mathrm{mg} / \mathrm{g}$ total toxic alkaloid) was determined chemically as previously described. ${ }^{8}$

\section{Cattle}

The steers were half-siblings from five breeds of cattle that were selected based on historic breed information and breed representation in gene chip technologies. Angus cattle were obtained from Snake River Cattle Company (Blackfoot, Idaho). Line 1 Herefords were obtained from Fort Keogh Livestock and Range Research Laboratory, Miles City, Montana. Line 1 Herefords represent a successful linebreeding program in which a high degree of relationship to the founding sire has been maintained for 18 generations. Holstein and Jersey steers were obtained from Double A Dairy (Wendell, Idaho). Brahman steers were obtained from Quintanilla/Casanova (Aldama, Mexico).

\section{Dosing Procedures}

Feed was withheld overnight before each steer was dosed with larkspur. On the morning of dosing, the steers were weighed and restrained in a squeeze chute. A standard alkaloid dose (8 mg/kg MLA; approximately 1.5 pounds, depending on the alkaloid concentration) in the form of dry, finely ground larkspur described above was administered via stomach tube in approximately 2 gallons of tap water. After oral dosing, the animals were closely monitored for the development of clinical signs. Twenty-four hours after oral dosing, the cattle were exercised as described below. Animal work was done under veterinary supervision with the approval and supervision of the Utah State University Institutional Animal Care and Use Committee.

\section{Exercise Protocol}

All animals were halter broke, tethered to a hitching rail behind a tractor as previously described by Cook et al. ${ }^{2}$ Groups of four or five haltered animals were tethered with a standard cotton lead rope to a 10-foot hitching rail with two feet of spacing on either side of the steer and hooked to a tractor. The animals were attached to the tow bar with a trailer tie and the cattle were exercised behind a tractor at 3-4 miles per hour on a dirt track for 40 minutes or until they exhibited larkspur-induced muscle weakness (collapse to sternal re- cumbency). If an animal exhibited larkspur-induced muscle weakness, the tractor was stopped, the time to clinical signs was recorded and the animal was quickly unhooked, after which the exercise was continued for the remaining animals. This procedure was continued for 40 minutes, or until all animals had exhibited signs of muscle weakness. The steers rested where they were unhooked from the tractor until they could easily walk without fatigue and then returned to their pen, typically within 30-90 minutes.

\section{Results and Discussion}

As described above, earlier research at the PPRL has identified animal-to-animal variation in cattle responses to larkspur. In this experiment, we attempted to measure larkspurinduced muscle weakness in five different breeds of cattle. These data were used quantify the responses of cattle to a standardized dose of tall larkspur, and to use those responses to identify and classify susceptible and resistant individuals within and between breeds. This information was used to calculate breed average responses for larkspur intoxication (Table 1). Angus cattle were selected for evaluation based on the current popularity of the breed. We selected the two dairy breeds for testing because they are genetically uniform but have distinct differences from beef breeds. ${ }^{9}$ Likewise, we used the inbred Line 1 Hereford cattle from Miles City, Montana because of their genetic uniformity, and DNA from the cow from the Miles City herd (L1 Dominette) was the basis for the bovine genome sequence. ${ }^{10} \mathrm{We}$ found

Table 1. Average time in minutes to exercise-induced clinical signs of poisoning in five breeds of cattle, each given a single dose of larkspur using a stomach tube

\begin{tabular}{|c|c|c|}
\hline Breed & No. animals & $\begin{array}{l}\text { Time to muscle } \\
\text { fatigue in minutes* }\end{array}$ \\
\hline Angus & 21 & $15.3 \pm 3.4$ \\
\hline Brahman & 13 & $9.4 \pm 3.3$ \\
\hline Line 1 Hereford & 36 & $8.8 \pm 1.8$ \\
\hline Holstein & 15 & $26.8 \pm 3.4^{+, \neq}$ \\
\hline Jersey & 14 & $29.3 \pm 2.9^{\dagger, \neq}$ \\
\hline \multicolumn{3}{|c|}{$\begin{array}{l}{ }^{\star} \text { Results represent the average time to muscle fatigue } \pm \\
\text { the standard error of the mean. } \\
{ }^{+} P<0.05 \text {, Hereford versus Holstein and Jersey, Dunn's } \\
\text { multiple comparison test. } \\
{ }^{\ddagger} P<0.05 \text {, Brahman versus Holstein and Jersey, Dunn's } \\
\text { multiple comparison test. }\end{array}$} \\
\hline
\end{tabular}


a three-fold difference in the breed average between Jersey cattle and the Line 1 Herefords in their response to a single larkspur dose. The observed difference between these breeds was most likely because of the founder effect due to a small number of individuals used to establish the breeds/ line. For example, Line 1 Herefords were founded by two sires, Advance Domino 20 and Advance Domino 54. ${ }^{10}$ The genetic diversity of Jersey cattle is lower than some breeds, and they have a very uniform genome when compared to other dairy breeds such as Holsteins. ${ }^{9}$ The genetic diversity of Holsteins is somewhat greater than Jersey cattle but their response to larkspur was nearly identical. In contrast to the dairy breeds, Brahman cattle have proven to be very susceptible to larkspur poisoning; this could result from differences in clearance of the larkspur toxins much like that seen between dairy and beef breeds. ${ }^{5,6}$

One unexpected and important result from this work was the identification of a diversity of responses between individuals within a breed. The Angus steers had the widest amount of separation between responses. For example, four Angus (Figure 5, green circle) walked for 40 minutes at 24 hours after dosing with larkspur, which we define as resistant. Conversely, six Angus (Figure 5, red circle) were too sensitive to be attached to the tow bar so they received a zero exercise time, which we define as sensitive. Results of the experiment with Angus cattle suggest that it might be possible to manage larkspur poisoning in cattle by selecting for resistant animals. Based on the results from Angus cattle, we speculate that out-bred Hereford cattle will have similar numbers of resistant individuals. All breeds tested to date have at least

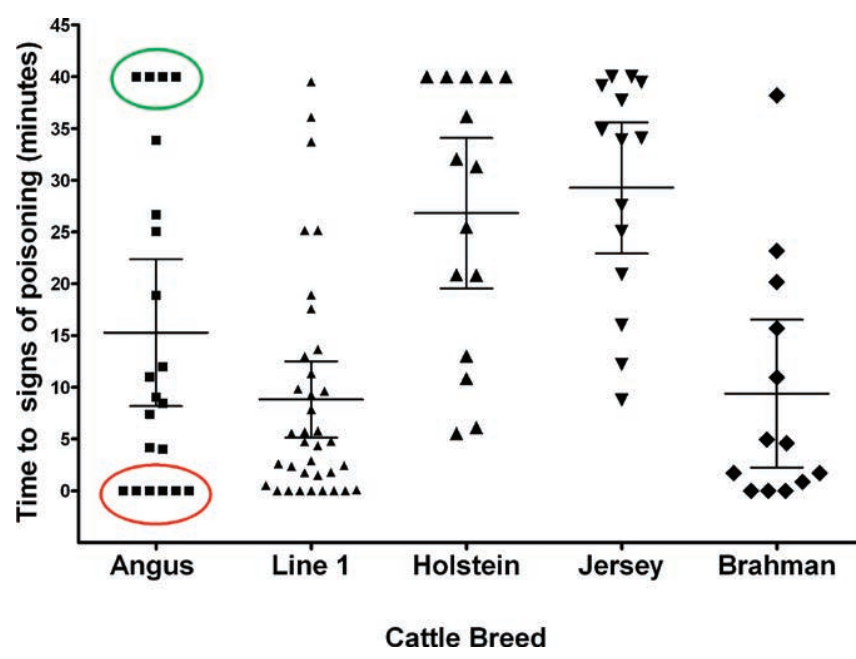

Figure 5. A scatter plot with the mean and 95\% confidence intervals for each breed depicting the responses to a standardized dose of tall larkspur ( $8 \mathrm{mg} / \mathrm{kg}$ total toxic alkaloid) at 24 hours after oral dosing. Line 1 represents Line 1 Herefords from Fort Keogh Livestock and Range Research Laboratory, Miles City, Montana. To determine the time to signs of poisoning, the cattle were exercised behind a tractor at 3-4 miles per hour on a dirt track for 40 minutes or until they exhibited larkspur-induced muscle weakness. Examples of resistant (green circle) and susceptible (red circle) animals are depicted for Angus. one individual resistant to larkspur poisoning. The number of larkspur-resistant animals might vary in each individual herd/breed due to the genetic background of that herd/breed. These differences are likely due to each individual animal's genetic predisposition for larkspur poisoning, which could be predicted from its DNA sequence. As stated above, it is likely that all breeds of cattle have larkspur-resistant individuals; the challenge now is to identify those resistant individuals for grazing on larkspur-infested rangelands.

\section{Future Directions}

In addition to screening individuals from five breeds of cattle, DNA samples have been obtained from every individual screened (see Figure 5 legend). We plan to use these samples for future genetic marker studies. The ultimate goal of this research is to identify a gene marker that will allow producers to identify susceptible and resistant animals by submitting a blood or hair sample to a genetic testing laboratory. Beef producers could then use that information for marker-assisted selection to improve the genetics of their herds for their specific range conditions. Currently, there are commercially available genetic tests for coat color, production traits, and meat quality (for more information, see Reference 11). The key to reducing risk on larkspur-containing rangelands will be the identification of larkspur-resistant individuals. By selecting resistant animals, the toxic window (Figure 4) can be narrowed and the productivity of larkspur-containing rangelands could be increased. We are also in the process of identifying resistant individuals for other toxic plants including lupine (Lupinus spp.) with a similar goal of finding a genetic marker that is associated with resistance to the intoxication. Ultimately, we hope to provide livestock producers with a means to select animals best suited to graze on pastures and rangelands with specific toxic plants such as larkspur and lupine.

\section{Acknowledgments}

The authors thank Isabelle McCollum, Clint Stonecipher, Nikki Nielson, Rex Probst, and Al Maciulis for their expert technical support. The current USDA Non-Discrimination Statement is located at http://usda.gov/wps/portal/usda/ usdahome?navid=NON_DISCRIMINATION.

\section{References}

1. Natural Resources Conservation Service (NRCS). PLANTS database. Available at: http://plants.usda.gov. Accessed 24 September 2013.

2. Cook, D., B. T. Green, K. D. Welch, D. R. Gardner, J. A. Pfister, And K. E. Panter. 2011. Comparison of the toxic effects of two duncecap larkspur (Delphinium occidentale) chemotypes in mice and cattle. American Journal of Veterinary Research 72:706-714.

3. Pfister, J. A., D. R. Gardner, B. L. Stegelmeier, K. HackETt, AND G. Secrist. 2003. Catastrophic cattle loss to low larkspur (Delphinium nuttallianum) in Idaho. Veterinary and Human Toxicology 45:137-139. 
4. Pfister, J. A., D. R. Gardner, K. E. Panter, G. D. Manners, M. H. Ralphs, B. L. Stegelmeier, and T. K. Schoch. 1999. Larkspur (Delphinium spp.) poisoning in livestock. Journal of Natural Toxins 8:81-94.

5. Green, B. T., K. D. Welch, D. R. Gardner, B. L. Stegelmeier, J. A. Pfister, D. Cook, and K. E. Panter. 2012. Toxicokinetics of norditerpenoid alkaloids from low larkspur (Delphinium andersonii) orally administered to cattle. American Journal of Veterinary Research 73:1318-1324.

6. Green, B. T., K. D. Welch, D. R. Gardner, B. L. StegelMEIER, AND S.T. LEE. 2013. A toxicokinetic comparison of two species of low larkspur (Delphinium spp.) in cattle. Research in Veterinary Science 95:612-615.

7. Green, B. T., J. A. Pfister, D. Cook, K. D. Welch, B. L. Stegelmeier, S. T. Lee, D. R. Gardner, E. L. Knoppel, and K. E. PANTER. 2009. Effects of larkspur (Delphinium barbeyi) on heart rate and electrically evoked electromyographic response of the external anal sphincter in cattle. American Journal of Veterinary Research 70:539-546.

8. Gardner, D. R., K. E. Panter,J.A. Pfister, and A.P. Knight. 1999. Analysis of toxic norditerpenoid alkaloids in Delphinium species by electrospray, atmospheric pressure chemical ionization, and sequential tandem mass spectrometry. Journal of Agricultural and Food Chemistry 47:5049-5058.
9. VanRaden, P. M., K. M. Olson, G. R. Wiggans, J. B. Cole, AND M. E.Tooker. 2011. Genomic inbreeding and relationships among Holsteins, Jerseys, and Brown Swiss. Journal of Dairy Science 94:5673-5682.

10. MacNeIL, M. D. 2009. Invited review: research contributions from seventy-five years of breeding Line 1 Hereford cattle at Miles City, Montana. Journal of Animal Science. 87:24892501.

11. Van Eenennaam, A. 2010. Commerically-available DNA test for beef cattle. University of California, Department of Animal Science. Davis, California, USA. Available at: http:// animalscience.ucdavis.edu/animalbiotech/Biotechnology/mas/ Commercially-available_DNA_tests_for_Beef_Cattle[1].pdf. Accessed 30 December 2013.

Authors are Research Pharmacologist, Ben.Green@ars.usda.gov (Green), Research Toxicologist (Welch), Research Rangeland Management Specialist (Pfister), Research Chemist (Gardner), and Supervisory Research Animal Scientist (Panter), USDAARS Poisonous Plant Research Laboratory, Logan, UT 84341, USA; and Research Immunologist (Chitko-McKown), USDAARS Genetics, Breeding, and Animal Health Research Unit, US Meat Animal Research Center, Clay Center, NE 68933. 